UDC 577.3

\title{
Histamine- and nicotine-stimulated modulations of mechanic activity of smooth muscles in gastrointestinal tract at the impact of nanosized $\mathrm{TiO}_{2}$ material
}

\author{
O. V. Tsymbaliuk ${ }^{1}$, A. M. Naumenkoㅇ, M. A. Skoryk ${ }^{2}$, O. Yu. Nyporko ${ }^{1}$, \\ T. L. Davidovska ${ }^{1}$, V. A. Skryshevsky ${ }^{1}$ \\ ${ }^{1}$ Institute of High Technologies, Taras Shevchenko National University of Kyiv \\ 2, korp. 5, Pr. Akademika Hlushkova, Kyiv, Ukraine, 03022 \\ ${ }^{2}$ NanoMedTech LLC \\ 68, Antonovycha Str., Kyiv, Ukraine, 03680 \\ otsymbal@bigmir.net,skoryk@nanomedtech.com.ua
}

\begin{abstract}
Aim. To investigate the influence of titanium dioxide nanoparticles $\left(\mathrm{TiO}_{2}\right)$ on histamine-, nicotine- (acetylcholine-nicotine)-stimulated modulations of mechanical activity in smooth muscles of caecum and stomach of rats. Methods. Electronic scanning microscopy; zeta-potential estimation; the isometric tension recordings; pharmacological and kinetic analysis. Results. Relaxation of smooth muscles stripes (SMS) of caecum stimulated by $10^{-5} \mathrm{~mol} / \mathrm{l}$ nicotine on the background of histamine contraction was not affected by $\mathrm{TiO}_{2}\left(10^{-3} \mathrm{mg} / \mathrm{ml}\right)$; under the same conditions $\mathrm{TiO}_{2}$ reinforced the histamine-induced contractions. The cumulative increase in $\mathrm{TiO}_{2}$ concentration in the $10^{-6}-10^{-4} \mathrm{mg} / \mathrm{ml}$ range was accompanied by inhibition of SMS contractions stimulated by histamine $\left(10^{-5} \mathrm{~mol} / \mathrm{l}\right)$ and nicotine $\left(10^{-7} \mathrm{~mol} / \mathrm{l}\right)$. Similar results were obtained on stomach SMS. The phase component of acetylcholine contraction modulated by nicotine was bound to be unaffected by $\mathrm{TiO}_{2}$ whereas the tonic component was inhibited. Conclusions. The suspension of $\mathrm{TiO}_{2}$ nanoparticles in conditions of cumulative effect modulates the mechanisms of neurotransmitter release from neurons of intramural plexuses of circular smooth muscle of the gastrointestinal tract which are activated by histamine and nicotine $\left(10^{-7} \mathrm{~mol} / \mathrm{l}\right)$.
\end{abstract}

Keywords: smooth muscles, contraction, pharmacomechanokinetics, histamine, cholinergic neurotransmission, titanium dioxide.

\section{Introduction}

A relevant role in the motility of the gastro-intestinal tract (GIT) is played by neurons of intramural nervous plexuses (INP). Via neuromediators they are involved in different kinds of inhibition-relaxation (purinergic, NO-ergic, vasointestinal, peptidergic, pituitary adenilate cyclase-activated peptidergic, adrenergic [1-5]) and excitation-contraction, respectively (tachykinininduced, cholinergic) $[6,7]$. It is known $[8,9]$ that there is presynaptic modulation of both excitation and inhibition processes in smooth muscles (SM) of intes- tines which occurs via chemoreceptors of membranes of nerve terminals, sensitive to both their "own" and "foreign" neuromediators. In particular, the regulators of the impact on the GIT motility are biogenic amines, namely, a highly active biogenic amine - histamine, with the participation of sympathetic postganglionic nervous fibers and smooth muscle cells (SMC) proper. Among the modulators of sympathetic and parasympathetic control (with the participation of autonomic ganglia) over the contraction activity of visceral smooth muscles, including smooth muscles of GIT, nicotine is noteworthy as an activator of nicotine

(C) 2016 O. V. Tsymbaliuk et al.; Published by the Institute of Molecular Biology and Genetics, NAS of Ukraine on behalf of Biopolymers and Cell. This is an Open Access article distributed under the terms of the Creative Commons Attribution License (http://creativecommons.org/licenses/by/4.0/), which permits unrestricted reuse, distribution, and reproduction in any medium, provided the original work is properly cited 
cholinoreceptors and natural alkaloid [9, 11]. However, the neuromotor system of GIT is a target for many biologically active substances, starting with bacterial substances [12, 13], and recently - with artificially created nanoconstructions, in particular, nanoparticles of titanium dioxide $\left(\mathrm{TiO}_{2}\right)$, the application of which is considerable in different sectors of world economy, especially food industry, with the purpose of processing products with this nanosized material [14]. $\mathrm{TiO}_{2}$ is also used in modern technologies of producing pharmacological preparations [15-17]. Still there is an open issue of the state of mechanisms of regulating the GIT motility, in particular, presynaptic modulation of excitation and inhibition processes of smooth muscles at the effect of nanosized material of titanium dioxide, which became the subject of our studies. In our work $\mathrm{TiO}_{2}$ was used in the form of nanopowder: a mixture of rutile and anatase. The structure of rutile is characterized by a system of channels, oriented in parallel with the crystallographic plane area. These channels may be presented in the cross section as a square with the $3.35 \AA$ side. Anatase is also characterized by a system of channels, located in parallel with the crystallographic plane area. The structures of anatase and rutile are presented in the form of three-dimensional chains, made of octahedrons of $\mathrm{TiO}_{2}$, where the central ion $\mathrm{Ti}^{+4}$ is surrounded with six anions $\mathrm{O}^{-2}$, four of which are in the equatorial plane, and two - in the axial peaks. In rutile the octahedrons are somewhat deformed, but they retain their orthorhombic symmetry. As for anatase, the distortions are more significant, which leads to the loss of orthorhombic symmetry. The bonds Ti-O in anatase are $1.980 \AA$ (equatorial) and $1.985 \AA$ Á (axial) [18] and are longer

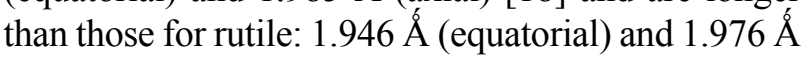
(axial) [19, 20].

\section{Materials and Methods}

\section{Investigation of contractile activity}

The experiments were conducted using isolated preparations of circular smooth muscles of caecum and antrum of outbred white rats with the weight of 250-300 g, regardless of their gender. The deflection of spontaneous rhythm activity, the excitation and inhibition of smooth muscle contractions, caused by exogenous application of neuromediators, were conducted by the strain gauge method, applied in isometric regime with subsequent analysis of their mechanokinetics. Standard Krebs was used in experiments with the following concentration of constituents (in mmol/l): $\mathrm{NaCl}-120.4 ; \mathrm{KCl}$ - 5.9; $\mathrm{NaHCO}_{3}-15.5 ; \mathrm{NaH}_{2} \mathrm{PO}_{4}-1.2 ; \mathrm{MgCl}_{2}$ - 1.2; $\mathrm{CaCl}_{2}-2.5$; glucose - 11.5; $\mathrm{pH}$ 7.4. The high potassium solution with $\mathrm{K}^{+}$concentration $(80 \mathrm{mmol} / \mathrm{l})$ was prepared by replacing the amount of sodium ions, required for the initial Krebs, with the equimolar amount of $\mathrm{K}^{+}$. The substances were used in the following concentrations: acetylcholine (AC) $10^{-5} \mathrm{~mol} / \mathrm{l}$; histamine $-10^{-5} \mathrm{~mol} / \mathrm{l}$; nicotine (NC) $10^{-7}$ and $10^{-3} \mathrm{~mol} / \mathrm{l}$.

\section{Preparation and characterization of $\mathrm{TiO}_{2}$ sus- pension}

The nanoparticles of $\mathrm{TiO}_{2}$ (PlasmaChem $\mathrm{GmbH}$, D-12489 Berlin, Germany) were used in the form of nanopowder (a mixture of rutile and anatase), the average size of particles being $(21 \pm 5) \mathrm{nm}$ (the measurements were conducted using a scanning electron microscope Tescan Mira 3 LMU) (Fig. 1), specific area $-(50 \pm 10)$ sq.m./g; purity $>99.5 \%$, content of $\mathrm{Al}_{2} \mathrm{O}_{3}<0.3 \%$ wt; $\mathrm{SiO}_{2}<0.2 \%$ wt. $\mathrm{TiO}_{2}$ nanopowder was previously resuspended in dimethyl sulfoxide (DMSO) assuming the presence of $0.25 \%$ of DMSO in the final volume. Likewise all the control solutions contained $0.25 \%$ of DMSO. The suspension of $\mathrm{TiO}_{2}$ particles was subjected to ultrasonic treatment for two minutes at the frequency of $37 \mathrm{kHz}$ to ruin the aggregates.

The zeta-potential of the suspension of $\mathrm{TiO}_{2}$ nanoparticles, estimated using Zetasizer nano device (kindly provided by NanoMedTech Company), was $(-7.93) \mathrm{mV}$. Titanium dioxide was used in the concentrations of $10^{-6}-10^{-3} \mathrm{mg} / \mathrm{ml}$.

\section{Mechanical-kinetic analysis of constructions}

The analysis of mechanokinetics of induced contractions and relaxations of smooth muscles was per- 


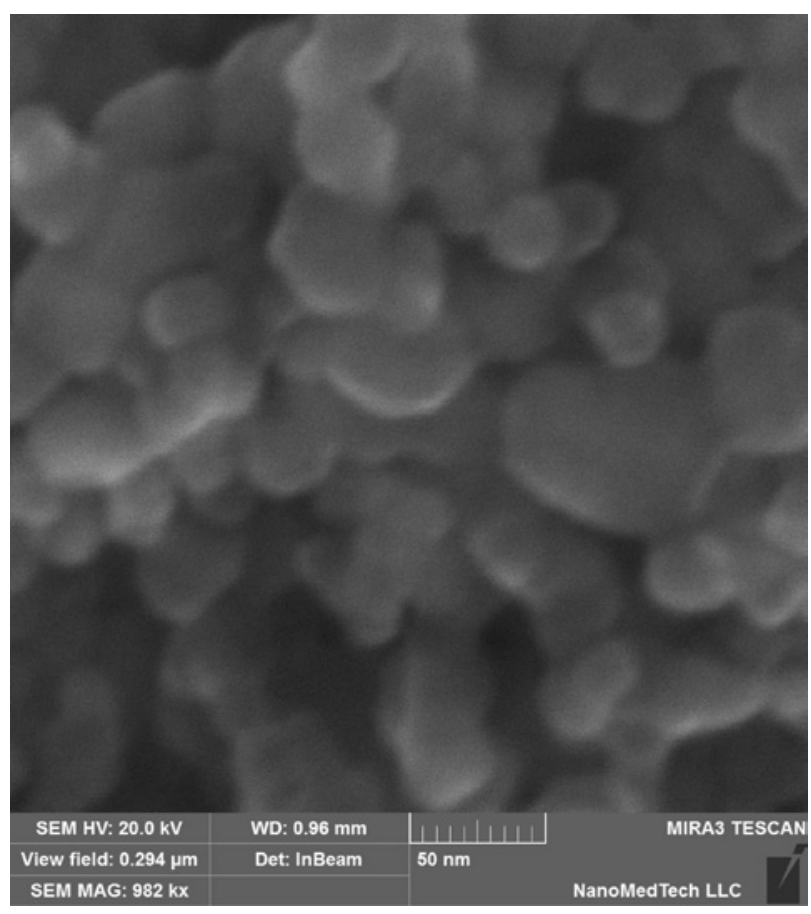

Fig. 1. Microphotograph of titanium dioxide nanoparticles

formed according to the method, described in [21] (Burdyga and Kosterin, 1991) with the consideration of normalized maximal velocities of contraction $\left(\mathrm{V}_{\mathrm{nc}}\right)$ and relaxation $\left(\mathrm{V}_{\mathrm{nr}}\right)$.

The value of $R$ parameter is $R=\left(A_{1} / A_{2}\right) \cdot 100 \%$, where $\left[A_{1} / A_{2}\right]$ - the ratio of the value of nicotineinduced relaxation (depending on the concentration of nicotine-induced contraction) of histamine-activated smooth muscles to the value of histamine-induced contraction of these muscules.

\section{Statistical analysis}

The statistical analysis of experiment results was performed using soft Microsoft Excel. Student's paired $t$-test was used to determine reliable differences between average values of two samplings; multiple comparisons were made using parametric one-factor dispersion analysis. The results were deemed reliable if the probability value $p$ was less than $5 \%(p<0.05)$. The results are presented as arithmetic mean \pm standard error of the mean, $n-$ number of experiments.

\section{Results and Discussion}

The effect of titanium dioxide suspension on histamine-stimulated contractions of smooth muscle stripes of caecum was investigated. The estimations of the level of random tone, amplitude and frequency of spontaneous contraction activity of SMS, performed in the control, demonstrated their stable values. It was established that titanium dioxide in the concentrations of $10^{-6}-10^{-3} \mathrm{mg} / \mathrm{ml}$ did not cause any significant changes in the muscle tone of preparations. Similar to our previous studies [22], $\mathrm{TiO}_{2}$ in the mentioned concentrations had dose-dependent inhibiting effect on the spontaneous contraction activity of muscle preparations. In the experiments (Fig. $2 a$ ) histamine in the concentration of $10^{-5} \mathrm{~mol} / \mathrm{l}$ was added with preparations to standard Krebs, and the SMS contraction accompanied with a further increase in the plateau-reaching muscle tone was observed. According to [23, 24], such contraction can be caused by two factors. One of them is a histamine capability to enhance the exciting cholinergic and non-adrenergic non-cholinergic neurotransmission via the participation of $\mathrm{H}_{2}$ histamine receptors of neurons of intramural nervous plexuses. The second cause is a direct histamine influence on the smooth muscle cells via $\mathrm{H}_{1}$ receptor-activated $\mathrm{IP}_{3}$-dependent signaling pathway that results in an increase of intracellular $\mathrm{Ca}^{2+}$ concentration and corresponding contraction of smooth muscles. In our experiments the maximal value of histamine-stimulated contractions of SMS was $2.8 \pm 0.5 \mathrm{mN}, \mathrm{n}=5$. When the curve of histamine-stimulated contraction reached the stationary level, standard Krebs with histamine and nicotine (natural activator of nicotine cholinoreceptors of neurons of autonomic ganglia) in the concentration of $10^{-5} \mathrm{~mol} / \mathrm{l}$ was added. Nicotine in the mentioned concentration led to partial relaxation of histamine-induced contraction of smooth muscles, related to the presence of nicotine cholinoreceptors on both cholinergic nerve terminals and terminals, containing inhibition mediators $[7,9,10]$. The replacement of the solution of the abovementioned composition with standard Krebs was accompanied with the restoration of the random level of muscle tone 
for SMS. The estimated average value of $\mathrm{R}$ parameter in the control was $(22 \pm 2) \%, n=7$. The duration of washing the muscle preparations with standard Krebs was 30-40 min, after which this solution was replaced with a similar one, containing $\mathrm{TiO}_{2}$ nanoparticles in the concentration of $10^{-3} \mathrm{mg} / \mathrm{ml}$. It was established that 20 min after application of this suspension, the random level of the background of muscle tone remained stable in time. The comparison with the control reveals an increase (by $(32.3 \pm 2.7) \%$,
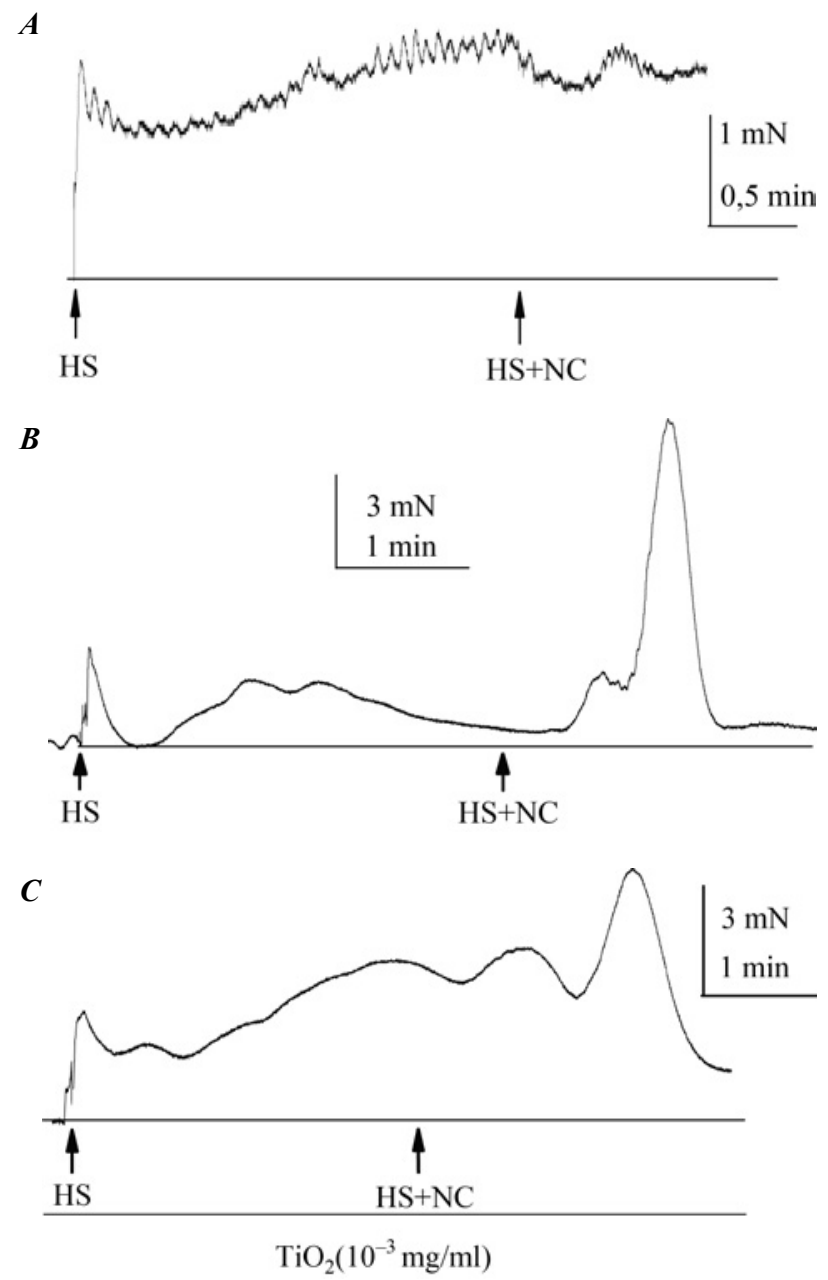

Fig. 2. The effect of histamine (HS) $\left(10^{-5} \mathrm{~mol} / \mathrm{l}\right)$ and nicotine (NC) (A: $\left.10^{-5} \mathrm{~mol} / \mathrm{l} ; \mathrm{B}: 10^{-7} \mathrm{~mol} / \mathrm{l}\right)$ on the muscle tone of smooth muscle stripes of caecum in the control $(\mathrm{A}, \mathrm{B})$ and at the effect of titanium dioxide $(\mathrm{C})$. The initial level of muscle tone is indicated with the dashed line. $\mathrm{n}=7, \mathrm{p}<0.05)$ in the value of SMS contraction, induced by histamine. Nicotine, applied in these conditions, caused partial relaxation of smooth muscle stripes, the degree of which remained at the control level. The effect of nicotine and histamine on smooth muscles of caecum stopped when standard Krebs, containing the mentioned substances and $\mathrm{TiO}_{2}$, was replaced with standard Krebs only. In these conditions there was no complete restoration of the degree of histamine-stimulated contraction during 3040 min washing of the preparations. Nicotine high concentration in the gastro-intestinal tract stimulate the inhibition neuromediators' release from intramural plexuses neurons and corresponding relaxation of smooth muscles, whereas low concentrations cause their contraction, mediated by the release of excitation neuromediators, acetylcholine, in particular [25, 26]. Taking the abovementioned into consideration, in the next series of experiments, conducted according to the described scheme, nicotine in the concentration of $10^{-7} \mathrm{~mol} / \mathrm{l}$ was added to the controls on the background of the histamine-induced contracture $\left(10^{-5} \mathrm{~mol} / \mathrm{l}\right)$, the maximal value of which was $(3 \pm 0.3)$ $\mathrm{mN}, \mathrm{n}=7$. As seen in Fig. $2 b$, nicotine in the mentioned concentration on the plateau of histamine-induced muscle tone of smooth muscle stripes caused the contraction; the ratio of its amplitude to the maximal value of the histamine-induced contraction was $(177 \pm 12.6) \%, n=7$. This excess in the amplitude of nicotine-induced contraction on the background of histamine effect is probably related to the release of a much greater number of excitation neuromediators out of the intramural plexuses neurons from muscle preparations compared to the activation of $\mathrm{H}_{2}$ histamine receptors. After washing the SMS with standard Krebs, titanium dioxide in the concentration of $10^{-3} \mathrm{mg} / \mathrm{ml}$ (application time - $20 \mathrm{~min}$ ) was added. It was established (Fig. 2c) that on the background of a histamine-induced increase in muscle tone there was a decrease in the value of SMS contraction, caused by nicotine in the abovementioned concentration $\mathrm{R}=(85.1 \pm 5.6) \%, \mathrm{n}=7, \mathrm{p}<0.05$.

The aim of the next experiment (Fig. 3) was to study the cumulative effect of $\mathrm{TiO}_{2}$ in the concentra- 
tions of $\left(10^{-6}-10^{-4}\right) \mathrm{mg} / \mathrm{ml}$ on histamine- $\left(10^{-5} \mathrm{~mol} / \mathrm{l}\right)$ and nicotine- $\left(10^{-7} \mathrm{~mol} / \mathrm{l}\right)$-induced contractions of SMS caecum on the background of histamine. The time of application of titanium dioxide for each concentration was $20 \mathrm{~min}$. It was established (Fig. $3 b$ ) that, compared to the control (Fig. $3 a$ ), $\mathrm{TiO}_{2}$ in the concentration of $10^{-6} \mathrm{mg} / \mathrm{ml}$ inhibited histamine-induced contractions of smooth muscles. Nicotine in the abovementioned concentration, applied on the background of histamine, did not cause any contraction of muscle preparations. As seen in Fig. $3 c$, at the $20^{\text {th }}$ minute of the cumulative effect of titanium dioxide in the concentration of $10^{-5} \mathrm{mg} / \mathrm{ml}$ the transformation of both histamine- and nicotine-induced contractures of SMS was observed. The inhibition of the latter compared to the control was $(78.2 \pm 6.5) \%$, $\mathrm{n}=7, \mathrm{p}<0.05$; in these conditions $\mathrm{R}$ parameter was $(50.3 \pm 4) \%, n=7, p<0.05$. Similar to the previous studies the solution of the abovementioned composition was replaced with standard Krebs, containing titanium dioxide in the concentration of $10^{-4} \mathrm{mg} / \mathrm{ml}$, the time of application of which was also $20 \mathrm{~min}$. The studies demonstrated (Fig. $3 d$ ) that the subsequent increase in $\mathrm{TiO}_{2}$ concentration by one order [of magnitude] was accompanied with the inhibition of both histamine-induced contraction and smooth muscles contraction, received in response to the application of nicotine $\left(10^{-7} \mathrm{~mol} / \mathrm{l}\right)$ on the background of histamine. Washing the muscle preparations with standard Krebs for 30-40 min did not lead to complete restoration of the degree of histamine contraction and nicotine-induced contraction on the background of histamine.

The next series of experiments estimated the effect of $\mathrm{TiO}_{2}$ on smooth muscles of caecum, activated by acetylcholine in combination with the application of nicotine (Fig. 4). In the control, to standard Krebs with smooth muscle stripes, acetylcholine in the concentration of $10^{-5} \mathrm{~mol} / \mathrm{l}$ was added. The contraction of muscle preparations was registered; the average value of its phase component and the ratio of the former to the tonic component were $(18 \pm 1.2) \mathrm{mN}$ and $(1.6 \pm 0.1), n=6$, respectively. Muscle preparations were washed with standard Krebs which re-

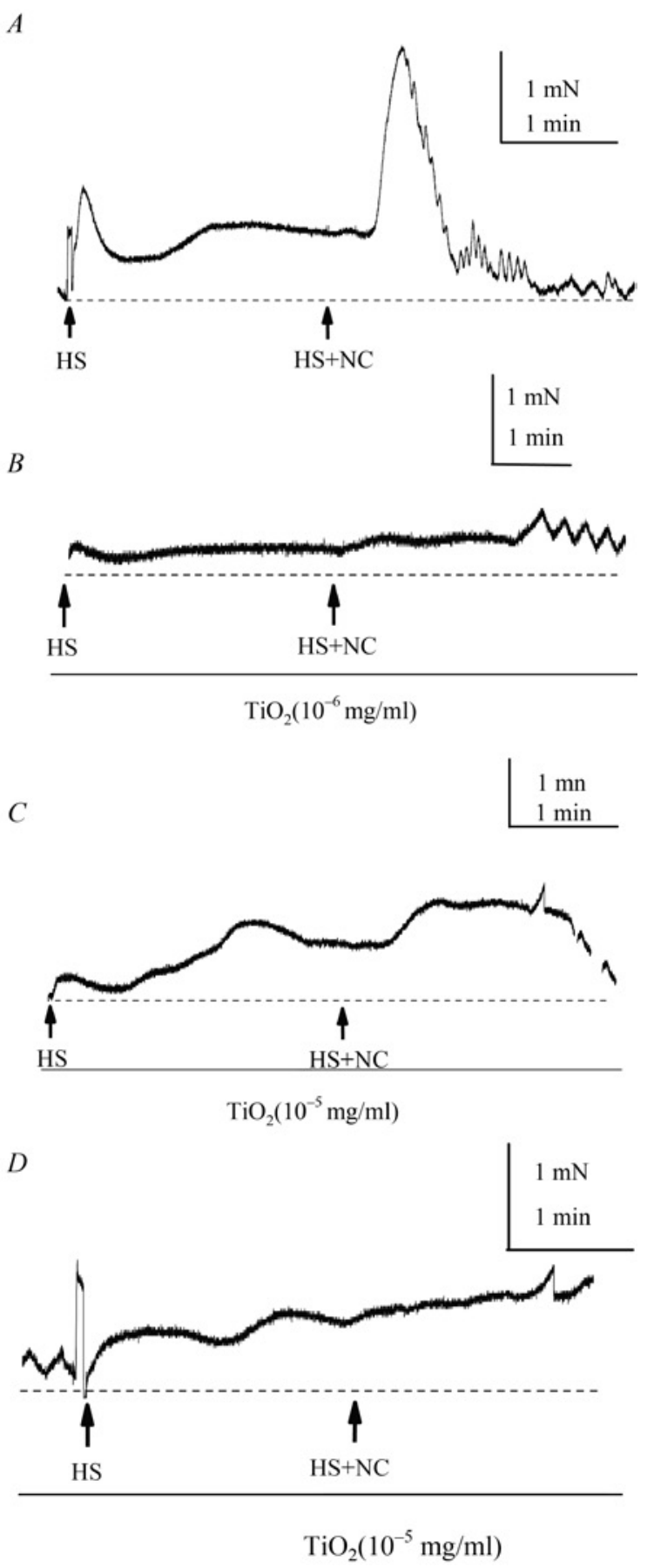

Fig. 3. The cumulative effect of titanium dioxide on nicotineinduced (NC) $\left(10^{-7} \mathrm{~mol} / \mathrm{l}\right)$ contraction of the smooth muscle stripe of caecum, activated with histamine (NS) $\left(10^{-5} \mathrm{~mol} / \mathrm{l}\right)$. control. The random level of muscle tone is indicated with the dashed line. 
sulted in the restoration of the random level of muscle tone. The tests were repeated twice, thrice, then acetylcholine in the abovementioned concentration and nicotine $\left(10^{-7} \mathrm{~mol} / \mathrm{l}\right)$ were added to standard
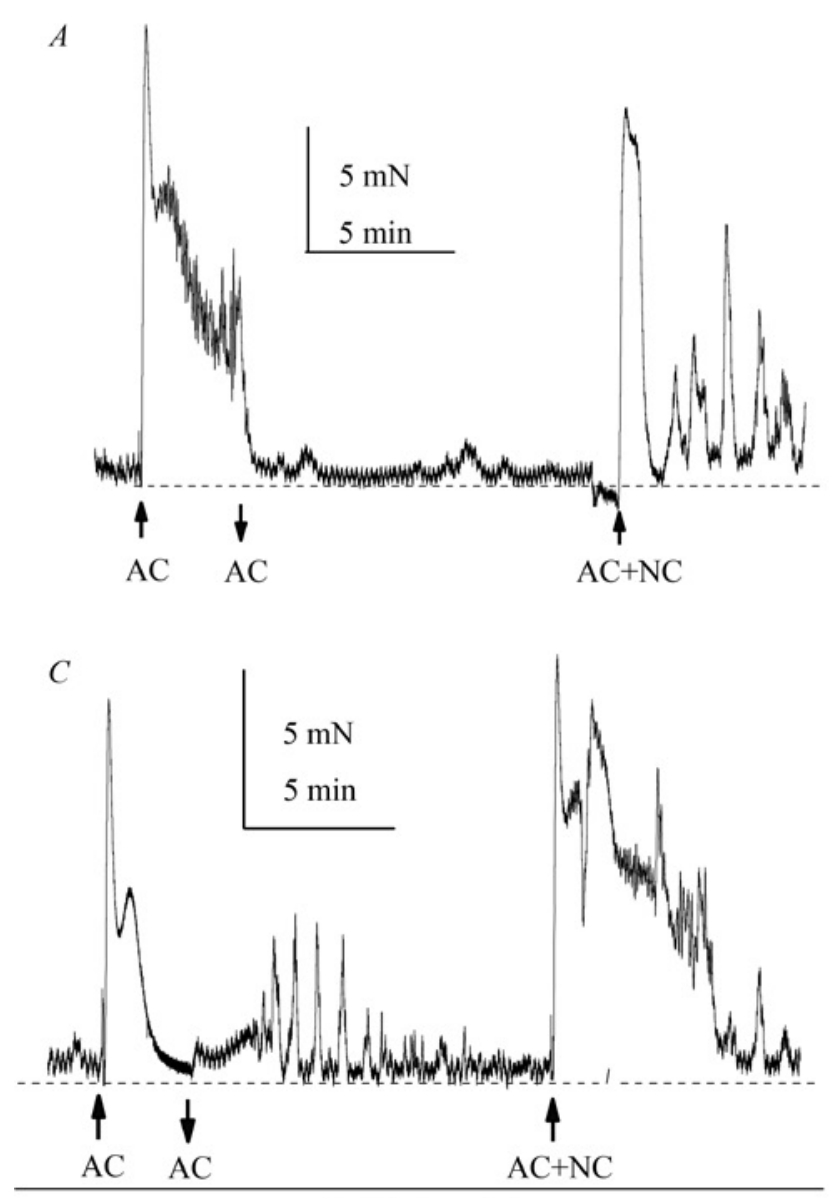

$\mathrm{TiO}_{2}\left(10^{-6} \mathrm{mg} / \mathrm{ml}\right)$

Fig. 4. The cumulative effect of titanium dioxide on the contraction of a smooth muscle stripe of caecum, caused by acetylcholine (AC) $\left(10^{-5} \mathrm{~mol} / \mathrm{l}\right)$, and by acetylcholine and nicotine (AC+NC) $\left(\left(10^{-5}\right.\right.$ and $\left.10^{-7}\right) \mathrm{mg} / \mathrm{ml}$, respectively). $A-$ control. The random level of muscle tone is indicated with the dashed line.
Krebs. As seen in Fig. 4a, there was a decrease in the value of phase component of acetylcholine contraction in the control and an increase in its tonic component, the ratio of which amounted to $(1.07 \pm 0.08)$,
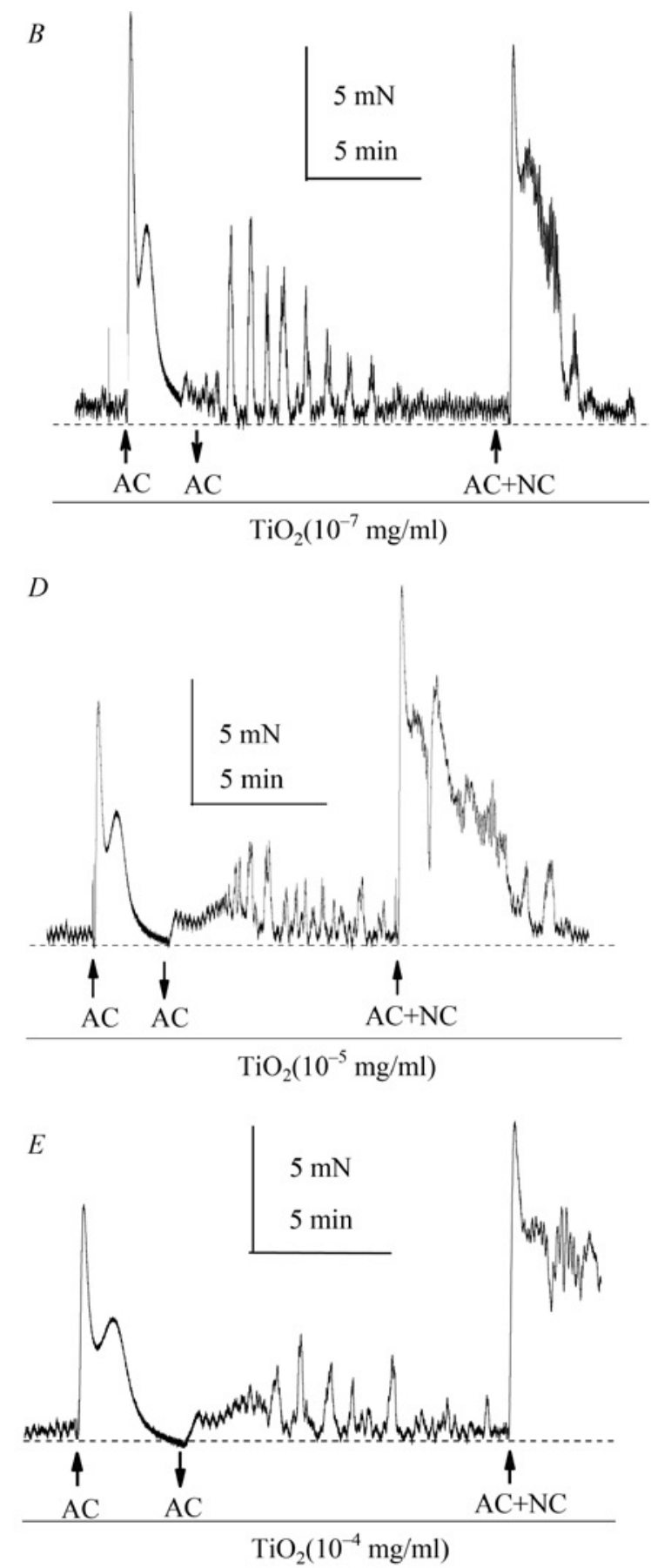
$\mathrm{n}=6$. It is known $[6,27-29]$ that the initiation of the primary phase of contraction, induced by acetylcholine, requires $\mathrm{M}_{3}$ receptor-mediated increase in the intracellular concentration of $\mathrm{Ca}^{2+}$ ions. At the same time the tonic component of this contraction is initiated by the activation of acetylcholine $\mathrm{M}_{2}$ cholinoreceptors. Their function is to inhibit the entry of extracellular $\mathrm{Ca}^{2+}$ ions via potential-directed $\mathrm{Ca}^{2+}$ channels of L-type which limits the entry of these cations into the cell during the cholinergic depolarization of its membrane. Taking the abovementioned into consideration, it is possible to assume that agonists, released from the neurons of intramural nervous plexuses of smooth muscle stripes under the impact of nicotine, modulate acetylcholine-activated $\mathrm{M}_{3}$ and $\mathrm{M}_{2}$ receptor-mediated intracellular signaling cascades. It results in corresponding decrease in the phase component and a considerable increase in the tonic component of acetylcholine contraction of caecum. After the control evaluations were completed according to the abovementioned scheme, the study was carried out on the cumulative effect of $\mathrm{TiO}_{2}$ in the concentrations of $\left(10^{-7}-10^{-4}\right) \mathrm{mg} / \mathrm{ml}$ on the contractions of smooth muscles, stimulated by acetylcholine and the combination of acetylcholine and nicotine (Fig. 4, $b, c, d, e$ ). The time of application of titanium dioxide for each concentration was 20 min. It was established that in the presence of $\mathrm{TiO}_{2}$ in the abovementioned concentrations there was more than two-fold decrease in the phase component of acetylcholine contractions, whereas its ratio to the tonic component compared to the control did not change and amounted to (1.6 \pm 0.1$), n=6, p<0.05$. In the same conditions the phase component of contractions of smooth muscle stripes, received in response to the simultaneous application of acetylcholine $\left(10^{-5} \mathrm{~mol} / \mathrm{l}\right)$ and nicotine $\left(10^{-7} \mathrm{~mol} / \mathrm{l}\right)$ did not change, whereas its ratio to the tonic component compared to the control $(1.07 \pm 0.08), \mathrm{n}=6$ increased considerably and reached its highest value (1.65 \pm 0.12$), \mathrm{n}=6, \mathrm{p}<0.05$ at $\mathrm{TiO}_{2}$ concentration of $10^{-4} \mathrm{mg} / \mathrm{ml}$ (Fig. $4 e$ ) (which corresponds to the ratio of these components of acetylcholine-induced contraction of SMS in the control $(1.6 \pm 0.1), n=6$
(Fig. 4a)). This decrease in the tonic component of acetylcholine-nicotine (AC-NC)-induced contraction of SM under the impact of $\mathrm{TiO}_{2}$ is probably related to its effect both on nicotine-modulated presynaptic mechanisms of releasing neuromediators from intramural nervous plexuses and on $\mathrm{M}_{2}$ receptor-activated by acetylcholine signaling cascade of smooth muscle cells, which results in dose-dependent restoration of the mechanisms of regulating $\mathrm{Ca}^{2+}$ ions input into SMC during the cholinergic depolarization of their membrane. As for the phase components of (AC-NC)-induced contraction at the cumulative effect of $\mathrm{TiO}_{2}$, regardless of a considerable decrease in acetylcholine-induced contraction compared to the control, its degree remained stable, contrary to the tonic component. The relative maximal contraction velocities of smooth muscle stripes, caused by acetylcholine and acetylcholine in combination with nicotine at the cumulative effect of $\mathrm{TiO}_{2}$, estimated according to the method described in [21] (Fig. 5), were almost identical. A similar result was obtained while estimating relative maximal velocities for SMS relaxation under the same conditions. In both cases the differences were observed only for the dynamics of changes in the mentioned parameters.

The cumulative effect of titanium dioxide on histamine-induced $\left(10^{-5} \mathrm{~mol} / \mathrm{l}\right)$ and nicotine-induced $\left(10^{-7} \mathrm{~mol} / \mathrm{l}\right)$ contractions of circular smooth muscles of rat stomach on the background of histamine effect was also studied according to the above described scheme. It was established that in the control the degree of SMS contraction of stomach, induced by histamine $\left(10^{-5} \mathrm{~mol} / \mathrm{l}\right)$, and by nicotine $\left(10^{-7} \mathrm{~mol} / \mathrm{l}\right)$ on the background of histamine effect $\left(10^{-5} \mathrm{~mol} / \mathrm{l}\right)$ exceeded similar contractions of smooth muscles of caecum more than six and four times, respectively, which indicates a much higher amount of $\mathrm{H}_{1}$ and $\mathrm{H}_{2}$ receptors, that compared to SMC of stomach and neurons of its intramural nervous plexuses, and more nicotine cholinoreceptors in INP as well. In both cases the washing of SMS with standard Krebs resulted in the restoration of the random level of muscle tone. In the experiments $\mathrm{TiO}_{2}$ in the concentra- 
tions of $\left(10^{-6}-10^{-4}\right) \mathrm{mg} / \mathrm{ml}$ compared to the control decreased the estimated parameters of contractions of muscle preparations (Fig. 6). Similar results were

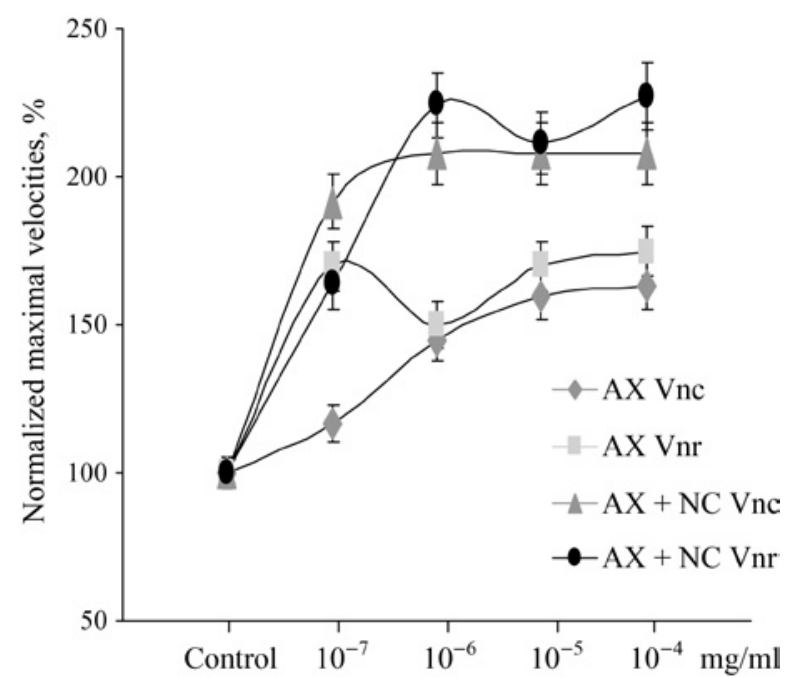

Fig. 5. The estimated normalized maximal velocities of contraction $\left(\mathrm{V}_{\mathrm{nc}}\right)$ - relaxation $\left(\mathrm{V}_{\mathrm{nr}}\right)$ of smooth muscle stripes of caecum, caused by acetylcholine (AC) $\left(10^{-7} \mathrm{~mol} / \mathrm{l}\right)$ and the combination of acetylcholine $\left(10^{-7} \mathrm{~mol} / \mathrm{l}\right)$ and nicotine $(\mathrm{NC})\left(10^{-7} \mathrm{~mol} / \mathrm{l}\right)$ in the control and at the cumulative effect of titanium dioxide.

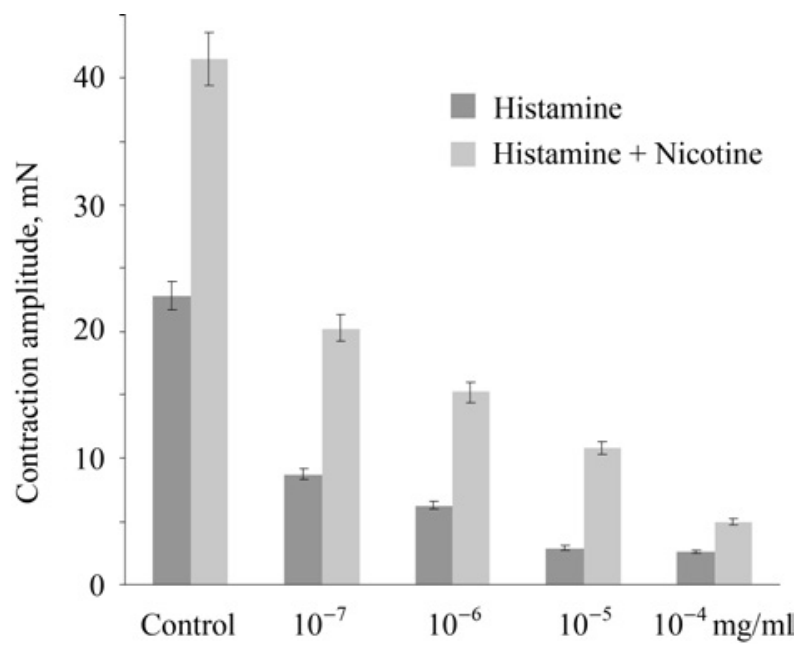

Fig. 6. The amplitude of histamine-induced $\left(10^{-5} \mathrm{~mol} / \mathrm{l}\right)$ and nicotine-induced $\left(10^{-7} \mathrm{~mol} / \mathrm{l}\right)$ contractions of smooth muscle stripes of circular smooth muscles of stomach on the background of histamine effect $\left(10^{-5} \mathrm{~mol} / \mathrm{l}\right)$ at the cumulative effect of titanium dioxide $\left(10^{-7}-10^{-4}\right) \mathrm{mg} / \mathrm{ml}$. obtained regarding the contractions of smooth muscle stripes, induced by acetylcholine $\left(10^{-5}\right) \mathrm{mol} / \mathrm{l}$.

\section{Conclusions}

Therefore, our results demonstrate that suspension of nanosized titanium dioxide causes a dose-dependent modulating effect on the contraction of circular smooth muscle stripes of stomach and caecum induced by the nicotine activation of cholinoreceptors. It is known that the nicotine effect on smooth muscles of the gastro-intestinal tract relates exclusively to its influence on the neurons of intramural nervous plexuses, the activation of which with low concentrations of this alkaloid is mediated by the release of acetylcholine, and with high concentrations - by the release of inhibition neuromediators. In our experiments the latter mechanism was found to be insensitive to the effect of $\mathrm{TiO}_{2}$, whereas the former one was inhibited with the suspension of these nanoparticles. The experiments revealed that the mechanisms of regulating the contractions of smooth muscles with the participation of both $\mathrm{H}_{2}$ histamine receptors of INP neurons and $\mathrm{H}_{1}$ receptors of smooth muscle cells are sensitive to the effect of $\mathrm{TiO}_{2}$. It has been also established that when nicotine modulates acetylcholine-stimulated contractions of smooth muscle stripes of caecum, $\mathrm{TiO}_{2}$ restores the mechanisms of regulating the input of $\mathrm{Ca}^{2+}$ ions in SMC during the cholinergic depolarization of their membrane.

\section{REFERENCES}

1. Burnstock $G$. Purinergic signalling in the gastrointestinal tract and related organs in health and disease. Purinergic Signal. 2014;10(1):3-50.

2. Philyppov IB, Vladimirova IA, Kulieva EM, Shuba YM. Involvement of secondary intracellular messengers in the mechanisms of purinergic inhibition of intestinal smooth muscles. Neurophysiology.2010;42(3):157-62.

3. Shuttleworth $C W$, Sweeney KM, Sanders KM. Evidence that nitric oxide acts as an inhibitory neurotransmitter supplying taenia from the guinea-pig caecum. Br J Pharmacol. 1999; 127(6):1495-501.

4. Lefebvre RA, Smits GJ, Timmermans JP. Study of NO and VIP as non-adrenergic non-cholinergic neurotransmitters in the pig gastric fundus. Br J Pharmacol. 1995;116(3):201726. 
5. Makhlouf GM, Murthy KS. Signal transduction in gastrointestinal smooth muscle. Cell Signal. 1997;9(3-4):269-76.

6. Zholos AV, Tsvilovskyy VV, Bolton TB. Muscarinic cholinergic excitation of smooth muscle: signal transduction and single cationic channel properties. Neurophysiology. 2003; 35(3/4):283-301.

7. Galligan JJ. Nerve terminal nicotinic cholinergic receptors on excitatory motoneurons in the myenteric plexus of guinea pig intestine. J Pharmacol Exp Ther. 1999;291(1):92-8.

8. Brookes SJ. Classes of enteric nerve cells in the guinea-pig small intestine. Anat Rec. 2001;262(1):58-70.

9. The IUPHAR compendium of receptor characterization and classification. London: "IUPHAR Media", 2000; 396 p.

10. Gabella $G$. The number of neurons in the small intestine of mice, guinea-pigs and sheep. Neuroscience. 1987;22(2): 737-52.

11. White TD. Release of ATP from isolated myenteric varicosities by nicotinic agonists. Eur J Pharmacol. 1982;79(3-4):333-4.

12. Melenevska NV, Miroshnychenko MS, Phylippov IB, Kholodna LS, Shuba MF. Effects of Staphylococcus aureus cell-bound protein A upon atp and nitric oxide inhibiting actions in smooth muscles. Fiziol Zh. 2006; 52(1):22-9.

13. Davydovs'ka TL, Tsymbaliuk OV, Danylova VM, Miroshnychenko MS, Kholodna LS, Posur VK. [Effect of staphylococcus active substances on ATPase activity of smooth muscle actomyosin and myosin]. Ukr Biokhim Zh (1999). 2001;73(4):24-8.

14. Warheit $D B$. How to measure hazards/risks following exposures to nanoscale or pigment-grade titanium dioxide particles. Toxicol Lett. 2013;220(2):193-204.

15. Jones K, Morton J, Smith I, Jurkschat K, Harding AH, Evans $G$. Human in vivo and in vitro studies on gastrointestinal absorption of titanium dioxide nanoparticles. Toxicol Lett. 2015;233(2):95-101.

16. Pele LC, Thoree V, Bruggraber SF, Koller D, Thompson RP, Lomer MC, Powell JJ. Pharmaceutical/food grade titanium dioxide particles are absorbed into the bloodstream of human volunteers. Part Fibre Toxicol. 2015;12:26.

17. Jovanović $B$. Critical review of public health regulations of titanium dioxide, a human food additive. Integr Environ Assess Manag. 2015;11(1):10-20.

18. Fahmi A, Minot C, Silvi B, Causá M. Theoretical analysis of the structures of titanium dioxide crystals. Phys Rev B Condens Matter. 1993;47(18):11717-24.

19. Myroniuk IF, Ostafiychuk BK, Gryhorchak II, Fedoriv VD, Kotsyubynsky VO, Chelyadyn VL, Pidluzhna AYu. Structure and electrochemical properties of nanoparticles of titania doped by iron. Physics and chemistry of solid state. 2006; 7(4): 687-94.

20. Burdett JK, Hughbanks T, Miller GJ, Richardson JW, Smith JV. Structural-electronic relationships in inorganic solids: powder neutron diffraction studies of the rutile and anatase polymorphs of titanium dioxide at 15 and $295 \mathrm{~K}$. J Am Chem Soc. 1987;109(12):3639-46.
21. Burdyga V, Kosterin SA. Kinetic analysis of smooth muscle relaxation. Gen Physiol Biophys. 1991;10(6):589-98.

22. Tsymbaliuk OV, Naumenko AM, Nyporko OYu, Davydovska TL, Skryshevsky VA. Excitation-inhibition of stomach smooth muscles by the nano-sized titanium dioxide materials. Dok Nac Acad Nauk Ukr. 2015; (10):85-92.

23. Poli E, Pozzoli C, Coruzzi G. Role of histamine H(3) receptors in the control of gastrointestinal motility. An overview. J Physiol Paris. 2001;95(1-6):67-74.

24. Bertaccini $G$, Corussi $G$. Histamine receptors in the digestive system. In: JC Schwarz, HL Haas (Eds). The histamine receptor. Wiley Liss, New York (NY), 1992; 193-230.

25. Galligan JJ. Nerve terminal nicotinic cholinergic receptors on excitatory motoneurons in the myenteric plexus of guinea pig intestine. J Pharmacol Exp Ther. 1999;291(1):92-8.

26. Gilman $A G$. Clinical pharmacology according to Goodman and Gilman - Moscow: "Praktika", 2006; 1648 p.

27. Hishinuma S, Matsumoto Y, Sato R, Saito M. Differential development of carbachol-induced desensitization in receptor-mediated $\mathrm{Ca} 2+$ influx and $\mathrm{Ca} 2+$ release pathways in smooth muscle of guinea-pig taenia caeci. Clin Exp Pharmacol Physiol. 2007;34(3):191-7.

28. Zholos $A V$. Regulation of TRP-like muscarinic cation current in gastrointestinal smooth muscle with special reference to PLC/InsP3/Ca2+ system. Acta Pharmacol Sin. 2006;27(7):833-42.

29. Bolton TB, Prestwich SA, Zholos AV, Gordienko DV. Excitation-contraction coupling in gastrointestinal and other smooth muscles. Annu Rev Physiol. 1999;61:85-115.

Гістамін-, нікотин-стимульовані модуляції механічної активності гладеньких м'язів шлунково-кишкового тракту за дії нанорозмірного матеріалу $\mathrm{TiO}_{2}$

О. В. Цимбалюк, А. М. Науменко, М. А. Скорик, О. Ю. Нипорко, Т. Л. Давидовська, В. А. Скришевський

Мета. Дослідити дію нанорозмірного матеріалу діоксиду титану $\left(\mathrm{TiO}_{2}\right)$ на гістамін-, нікотин- (ацетилхолін-нікотин) -стимульовані модуляції механічної активності гладеньких м'язів caecum та шлунку щурів. Методи. Електронна скануюча мікроскопія; визначення дзета-потенціалу; реєстрація скоротливої активності в ізометричному режимі; фармакологічний і кінетичний аналіз. Результати. Встановлено, що викликане нікотином $\left(10^{-5}\right.$ моль/л) розслаблення гладеньком'язових смужок (ГМС) саесит на фоні гістамінової (10-5 моль/л) контрактури не чутливе до дії $\mathrm{TiO}_{2}\left(10^{-3}\right.$ мг/мл); за цих умов $\mathrm{TiO}_{2}$ підсилював гістамінові скорочення. Кумулятивне збільшення концентрації $\mathrm{TiO}_{2}\left(10^{-6}-10^{-4}\right.$ мг/мл) супроводжувалось пригніченням скорочень ГМС, викликаних гістаміном $\left(10^{-5}\right.$ моль/л) та нікотином у концентрації $10^{-7}$ моль/л. Аналогічні результати було одержано у дослідах на ГМС шлунку. Встановлено, що фазний компонент ацетилхолінового скорочення, модульованого нікотином, не чутливий до дії $\mathrm{TiO}_{2}$, тоді як тонічний - пригнічуєть- 
ся. Висновки. Суспензія наночастинок $\mathrm{TiO}_{2}$ за умов кумулятивної дії модулює активовані гістаміном та на його фоні - нікотином (10-7 моль/л) механізми вивільнення нейромедіаторів 3 нейронів інтрамурального нервового плетива кільцевих гладеньких м'язів шлунково-кишкового тракту.

Ключ ов і сл ов а: гладенькі м'язи, скорочення, фармакомеханокінетика, гістамін, холінергічна нейропередача, діоксид титану.

Гистамин-, никотин- стимулированные модуляции механической активности гладких мышц желудочнокишечного тракта за действия наноразмерного материала $\mathrm{TiO}_{2}$

О. В. Цимбалюк, А. Н. Науменко, Н. А. Скорик, А. Ю. Ныпорко, Т. Л. Давидовская, В. А. Скрышевский

Цель. Исследовать действие наноразмерного материала диоксида титана $\left(\mathrm{TiO}_{2}\right)$ на гистамин-, никотин- (ацетилхолин-никотин) -стимулированные модуляции механической активности гладких мышц саесит и желудка крыс. Методы. Электронная сканирующая микроскопия; определение дзета-потенциала; регистрация сократительной активности в изометрическом режиме; фармакологический и кинетический анализ. Результаты. Установлено, что вызванное нико- тином $\left(10^{-5}\right.$ моль/л) расслабление гладкомышечных полосок (ГМП) caеcum на фоне гистаминовой $\left(10^{-5}\right.$ моль/л) контрактуры не чувствительно к действию $\mathrm{TiO}_{2}\left(10^{-3}\right.$ мг/мл); за этих условий $\mathrm{TiO}_{2}$ усиливал гистаминовые сокращения. Кумулятивное увеличение концентрации $\mathrm{TiO}_{2}\left(10^{-6}-10^{-4}\right.$ мг/мл) сопровождалось угнетением сокращений ГМП, вызванных гистамином $\left(10^{-5}\right.$ моль/л) и никотином в концентрации $10^{-7}$ моль/л. Аналогичные результаты было получено в опытах на ГМП желудка. Установлено, что фазный компонент ацетилхолинового сокращения, модулированного никотином, не чувствительный к действию $\mathrm{TiO}_{2}$, тогда как тонический угнетается. Выводы. Суспензия наночастиц $\mathrm{TiO}_{2}$ при условии кумулятивного действия модулирует активированные гистамином и на его фоне - никотином (10-7 моль/л) механизмы высвобождения нейромедиаторов с нейронов интрамурального нервного плетения кольцевых гладких мышц желудочно-кишечного тракта.

Кл юч е в ы е сл о в а: гладкие мышцы, сокращения, фармакомеханокинетика, гистамин, холинергическая нейропередача, диоксид титана.

Received 19.10.2015 